\title{
Teachers' Acceptance towards the Inclusive Education Program for Students with Hearing Impairment
}

\author{
Rohaizat Ibrahim, Liyana Abd Talib \\ Faculty of Education, Universiti Kebangsaan Malaysia, Bangi, Selangor, 43600, Malaysia \\ Email: mhmy6365@ukm.edu.my
}

\begin{abstract}
This research discussed the teachers' acceptance towards the inclusive education program. The purpose of the research was to identify how the teachers accept the program for students with hearing disabilities. This research was also conducted to gather suggestions on ways to improve the program through the gatherings of opinions from these teachers. Thirty mainstream teachers from a school in Melaka were chosen as respondents based on the criteria that their school has an integrated program for students with hearing disabilities and applies this program to these students in classes. Data was collected by randomly distributing questionnaires to respondents and analyzed using the Statistical Package for Social Science (SPSS V22). The research result showed that teachers accept the inclusive education program positively. This research put forward suggestions as guidelines to the public and hopes that in the future more research could be done on this program with multiple objectives and concepts.
\end{abstract}

Keywords: teachers' acceptance, inclusive education program, students with hearing impairment

\section{INTRODUCTION}

The inclusive education program is a school that integrates one to five special needs students into a regular class (Buku Pelan Pembangunan Pendidikan Malaysia, 2013-2025). Miles and Singal (2010) stated that students with special needs must have access to these schools. These schools are the best solution to overcome discrimination and create an open-minded as well as an inclusive community. Article 28 in People with Disabilities Act 2008 emphasized that students with special needs must be given support to help them achieve equality in education.

Each student should receive an equal amount of education without taking gender, religion, race or individual differences into account through the inclusive education program. (Yasin, Toran, \& Shaari, 2008) stated that the assertion on the foundation of education for all was mentioned in the Jomtien World Conference 1990 which took place in Thailand.

Through this program, students with hearing impairment will get to learn with normal students in the same class. They are taught by teachers who are aided by special education teachers. This program is to encourage interaction between these impaired students with normal students in spite of individual differences and functions as a process to lessen separation as well as to increase the participation of students in the school's culture, curriculum and community (Booth \& Ainscow, 2002).

According to Valeo (2008), teachers with positive attitude will teach better in this program. Therefore, the success in executing it depends on a combination of attitude, skill and knowledge to educate students with hearing impairment. These three components are crucial in assuring that teachers are ready to execute this program to these students.

Research has shown that teachers in Malaysia do have a positive perception of this program but they lack participation in executing it (Ali et al., 2006; Zalizan, 2012). Nevertheless, Teng et al. (2006) claimed that teachers are the frontline to successfully execute the inclusive education program.

\section{Methods}

The research was conducted using the survey method by distributing questionnaires to teachers. The purpose of this survey was to gauge the level of acceptance among respondents towards the inclusive education program for students with hearing impairment. According to Konting (2004), a survey is an instrument to gather information on facts, beliefs, feelings, desires and others. The research population consisted of thirty secondary schools teachers from various schools in Melaka.

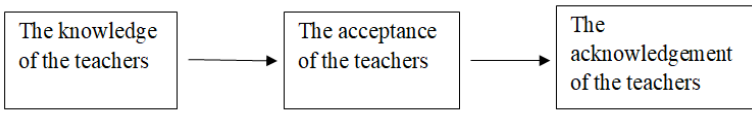

Figure 1. The Research Concept Model 
Table 1. Mean Score Interpretation

\begin{tabular}{ll}
\hline Level & Mean Score \\
\hline High & $3.68-5.00$ \\
Average & $2.34-3.67$ \\
Low & $1.00-2.33$ \\
\hline
\end{tabular}

Table 2. Respondents' Demographic Information

\begin{tabular}{|c|c|c|c|c|}
\hline No & Item & Category & Number & Percentage $(\%)$ \\
\hline \multirow[t]{2}{*}{1} & \multirow[t]{2}{*}{ Gender } & Male & 11 & 36.7 \\
\hline & & Female & 19 & 63.3 \\
\hline \multirow[t]{5}{*}{2} & \multirow[t]{5}{*}{ Teaching experiences } & $<1$ year & 0 & 0 \\
\hline & & $<5$ years & 0 & 0 \\
\hline & & $5-10$ years & 9 & 30.0 \\
\hline & & 10-15 years & 11 & 36.7 \\
\hline & & $>15$ years & 10 & 33.3 \\
\hline \multirow[t]{3}{*}{3} & \multirow[t]{3}{*}{ Academic level } & Diploma & 0 & 0 \\
\hline & & Degree & 30 & 100 \\
\hline & & Masters/PHD & 0 & 0 \\
\hline \multirow[t]{10}{*}{4} & \multirow[t]{10}{*}{ Specialized area } & Bahasa Melayu & 4 & 13.3 \\
\hline & & English & 3 & 10.0 \\
\hline & & Mathematics & 5 & 16.7 \\
\hline & & History & 4 & 13.3 \\
\hline & & Islamic Education & 3 & 10.0 \\
\hline & & Science & 4 & 13.3 \\
\hline & & Living Skills & 2 & 6.7 \\
\hline & & Geography & 3 & 10.0 \\
\hline & & Sports and & 2 & 6.7 \\
\hline & & Recreation & & \\
\hline \multirow[t]{2}{*}{4} & \multirow{2}{*}{$\begin{array}{l}\text { Experience with students } \\
\text { with hearing disabilities }\end{array}$} & Yes & 22 & 73.3 \\
\hline & & No & 8 & 26.7 \\
\hline \multirow[t]{2}{*}{5} & \multirow{2}{*}{$\begin{array}{l}\text { Teaching experience with } \\
\text { students } \\
\text { disabilities }\end{array}$} & Yes & 1 & 3.3 \\
\hline & & No & 29 & 96.7 \\
\hline $\mathrm{N}$ & & 30 people & & \\
\hline
\end{tabular}

The survey was divided into four sections. Section A contained items on demography while Sections B and $\mathrm{C}$ respectively focused on the level of acceptance as well as knowledge of teachers on the inclusive education program. Section D stated items on the use of teaching aids and classroom management for these teachers in inclusive class. Sections B, C and D used the Likert Scale method by having five choice answers, which were Strongly Disagree, Disagree, Not Sure, Agree and Strongly Agree.

The collected data were analyzed using the Statistical Package for Social Science (SPSS V22). The researchers used the mean score interpretation listed in Table 1 below and it was divided into three levels which are low, intermediate and high.

\section{FINDINGS AND DISCUSSION}

\section{Findings}

Section A. Demographic of Respondents

This section contained items related to the demographic factors of respondents on gender, teaching experiences, academic level, area of specialization, as well as experiences in handling and teaching students with hearing impairment. The findings are shown in Table 2. To determine the level for the collected data, the researchers used the mean score interpretation listed in Table 3. The score was divided into three levels which are low, intermediate and high. 
Table 3. Mean Score Interpretation

\begin{tabular}{ll}
\hline Level & Mean Score \\
\hline High & $3.68-5.00$ \\
Average & $2.34-3.67$ \\
Low & $1.00-2.33$ \\
\hline
\end{tabular}

Table 4. Acceptance Level of the Teachers on Inclusive Education Program

\begin{tabular}{|c|c|c|c|c|c|c|c|c|}
\hline \multirow{2}{*}{$\begin{array}{l}\text { Item } \\
\text { No }\end{array}$} & \multirow[t]{2}{*}{ Question } & \multicolumn{5}{|c|}{ Scale } & \multirow[t]{2}{*}{ Mean } & \multirow[t]{2}{*}{ Level } \\
\hline & & $\begin{array}{l}\text { STS } \\
f(\%)\end{array}$ & $\begin{array}{c}\text { TS } \\
f(\%)\end{array}$ & $\begin{array}{c}\mathrm{TP} \\
f(\%)\end{array}$ & $\begin{array}{c}\mathrm{S} \\
f(\%)\end{array}$ & $\begin{array}{c}\text { SS } \\
f(\%)\end{array}$ & & \\
\hline \multirow[t]{2}{*}{1} & \multirow{2}{*}{$\begin{array}{l}\text { I am prepared to understand the } \\
\text { needs of these students to create a } \\
\text { meaningful learning }\end{array}$} & 0 & 0 & 1 & 27 & 2 & \multirow[t]{2}{*}{4.03} & \multirow[t]{2}{*}{ High } \\
\hline & & 0.0 & 0.0 & 3.3 & 90.0 & 6.7 & & \\
\hline \multirow[t]{2}{*}{2} & \multirow{2}{*}{$\begin{array}{l}\text { I am prepared to make physical } \\
\text { changes in class if the need arises }\end{array}$} & 0 & 0 & 2 & 25 & 3 & \multirow[t]{2}{*}{4.03} & \multirow[t]{2}{*}{ High } \\
\hline & & 0.0 & 0.0 & 6.7 & 83.3 & 10.0 & & \\
\hline \multirow[t]{2}{*}{3} & \multirow{2}{*}{$\begin{array}{l}\text { I am prepared to explore the } \\
\text { needs of these students to create a } \\
\text { meaningful learning }\end{array}$} & 0 & 0 & 3 & 23 & 4 & \multirow[t]{2}{*}{4.03} & \multirow[t]{2}{*}{ High } \\
\hline & & 0.0 & 0.0 & 10.0 & 76.7 & 13.3 & & \\
\hline \multirow[t]{2}{*}{4} & \multirow{2}{*}{$\begin{array}{l}\text { I understand the concept of } \\
\text { inclusive education program }\end{array}$} & 1 & 0 & 9 & 18 & 2 & \multirow[t]{2}{*}{3.67} & \multirow[t]{2}{*}{ Average } \\
\hline & & 3.3 & 0.0 & 30.0 & 60.0 & 6.7 & & \\
\hline \multirow[t]{2}{*}{5} & \multirow{2}{*}{$\begin{array}{l}\text { I am prepared to attend courses to } \\
\text { increase the level of efficiency in } \\
\text { an inclusive class }\end{array}$} & 0 & 1 & 6 & 20 & 3 & \multirow[t]{2}{*}{3.83} & \multirow[t]{2}{*}{ High } \\
\hline & & 0.0 & 3.3 & 20.0 & 66.7 & 10.0 & & \\
\hline \multirow[t]{2}{*}{6} & \multirow{2}{*}{$\begin{array}{l}\text { I am prepared to consult the special } \\
\text { education teachers in helping these } \\
\text { students }\end{array}$} & 0 & 0 & 5 & 24 & 1 & \multirow[t]{2}{*}{3.87} & \multirow[t]{2}{*}{ High } \\
\hline & & 0.0 & 0.0 & 16.7 & 80.0 & 3.3 & & \\
\hline \multirow[t]{2}{*}{7} & \multirow{2}{*}{$\begin{array}{l}\text { If these students were to be placed } \\
\text { in my class, I am prepared to } \\
\text { befriend them to gauge their level } \\
\text { of understanding of my teaching }\end{array}$} & 0 & 0 & 2 & 26 & 2 & \multirow[t]{2}{*}{4.00} & \multirow[t]{2}{*}{ High } \\
\hline & & 0.0 & 0.0 & 6.7 & 86.7 & 6.7 & & \\
\hline 8 & I am prepared to give my full & 0 & 0 & 10 & 19 & 1 & 3.70 & High \\
\hline & $\begin{array}{l}\text { attention to the learning session in } \\
\text { an inclusive class }\end{array}$ & 0.0 & 0.0 & 33.3 & 63.3 & 3.3 & & \\
\hline 9 & I am prepared to accept these & 0 & 0 & 3 & 23 & 4 & 4.03 & High \\
\hline & negative feelings & 0.0 & 0.0 & 10.0 & 76.7 & 13.3 & & \\
\hline 10 & I feel that teaching in an inclusive & 2 & 1 & 10 & 14 & 3 & 3.50 & Average \\
\hline & & 6.7 & 3.3 & 33.3 & 46.7 & 10.0 & & \\
\hline & $\begin{array}{l}\text { Total }(\mathrm{N})=30 \text { people } \\
\text { Overall mean }\end{array}$ & & & & & & 3.8 & High \\
\hline
\end{tabular}

Section B: The Acceptance of Teachers on Inclusive Education Program

The result of analysis on the acceptance level of teachers was based on these items in table 4. Based on the information provided in the table, the first statement which was "I am prepared to understand the needs of these students to create a meaningful learning" shows a mean score of 4.3. Overall, the mean score for the acceptance level of the teachers on the inclusive education program is high, which was 3.8. The findings by Block et al. (2007) supported the findings of this research where it shows that teachers have a positive acceptance of this program. The commitment shown gives the teachers the much needed space and time to respect the attitude and opinion of these students. However, the findings of this research contrasted with the findings of Costello and Boyle (2013) where they said that the teachers' attitudes are less positive after a year of teaching these students due to a cquirement of experiences and understanding of their tasks. 
Section C: Teachers' Knowledge on Inclusive Education Program

Table 5. The Knowledge Level of Teachers on Inclusive Education

\begin{tabular}{|c|c|c|c|c|c|c|c|c|}
\hline \multirow{2}{*}{$\begin{array}{l}\text { Item } \\
\text { No }\end{array}$} & \multirow[t]{2}{*}{ Question } & \multicolumn{5}{|c|}{ Scale } & \multirow[t]{2}{*}{ Mean } & \multirow[t]{2}{*}{ Level } \\
\hline & & $\begin{array}{l}\text { STS } \\
f \\
(\%)\end{array}$ & $\begin{array}{c}\mathrm{TS} \\
f \\
(\%)\end{array}$ & $\begin{array}{c}\mathrm{TP} \\
f \\
(\%)\end{array}$ & $\begin{array}{c}\mathrm{S} \\
f \\
(\%)\end{array}$ & $\begin{array}{c}\mathrm{SS} \\
f \\
(\%)\end{array}$ & & \\
\hline \multirow[t]{2}{*}{11} & \multirow{2}{*}{$\begin{array}{l}\text { Inclusive education is a program where } \\
\text { special education students are placed in a } \\
\text { mainstream class }\end{array}$} & 0 & 0 & 1 & 25 & 4 & \multirow[t]{2}{*}{4.10} & \multirow[t]{2}{*}{ High } \\
\hline & & 0.0 & 0.0 & 3.3 & 83.3 & 13.3 & & \\
\hline \multirow[t]{2}{*}{12} & \multirow{2}{*}{$\begin{array}{l}\text { Inclusive education is an approach to } \\
\text { improve the education level of special } \\
\text { education students by placing them in a } \\
\text { mainstream class }\end{array}$} & 0 & 1 & 4 & 23 & 2 & \multirow[t]{2}{*}{3.87} & \multirow[t]{2}{*}{ High } \\
\hline & & 0.0 & 3.3 & 13.3 & 76.7 & 6.7 & & \\
\hline \multirow[t]{2}{*}{13} & \multirow{2}{*}{$\begin{array}{l}\text { These students will be in a fulltime } \\
\text { mainstream class that is equipped with } \\
\text { extra facilities }\end{array}$} & 0 & 0 & 3 & 25 & 2 & \multirow[t]{2}{*}{3.97} & \multirow[t]{2}{*}{ High } \\
\hline & & 0.0 & 0.0 & 10.0 & 83.3 & 6.7 & & \\
\hline \multirow[t]{2}{*}{14} & Inclusive education uses the approach of & 0 & 0 & 3 & 25 & 2 & \multirow[t]{2}{*}{3.97} & \multirow[t]{2}{*}{ High } \\
\hline & $\begin{array}{l}\text { co-teaching where the mainstream and } \\
\text { special education teachers will teach in } \\
\text { the same class. }\end{array}$ & 0.0 & 0.0 & 10.0 & 83.3 & 6.7 & & \\
\hline \multirow[t]{2}{*}{15} & \multirow{2}{*}{$\begin{array}{l}\text { Inclusive education gives an opportunity } \\
\text { to special education students to interact } \\
\text { and participate in learning activities and } \\
\text { experience an effective and meaningful } \\
\text { spirit of belonging to a school }\end{array}$} & 0 & 0 & 3 & 25 & 2 & \multirow[t]{2}{*}{3.97} & \multirow[t]{2}{*}{ High } \\
\hline & & 0.0 & 0.0 & 10.0 & 83.3 & 6.7 & & \\
\hline \multirow[t]{2}{*}{16} & $\begin{array}{l}\text { Inclusive education is an effort to } \\
\text { normalize any defects by closing the }\end{array}$ & 0 & 0 & 3 & 24 & 3 & \multirow[t]{2}{*}{4.00} & \multirow[t]{2}{*}{ High } \\
\hline & $\begin{array}{l}\text { gap between special education with } \\
\text { mainstream education }\end{array}$ & 0.0 & 0.0 & 10.0 & 80.0 & 10.0 & & \\
\hline \multirow[t]{2}{*}{17} & \multirow{2}{*}{$\begin{array}{l}\text { The three main techniques use in inclusive } \\
\text { education are co-teaching, collaboration } \\
\text { and support teaching }\end{array}$} & 0 & 0 & 3 & 27 & 0 & \multirow[t]{2}{*}{3.90} & \multirow[t]{2}{*}{ High } \\
\hline & & 0.0 & 0.0 & 10.0 & 90.0 & 0.0 & & \\
\hline \multirow[t]{2}{*}{18} & $\begin{array}{l}\text { The implementation of the inclusive } \\
\text { education program focuses on giving }\end{array}$ & 0 & 0 & 3 & 25 & 2 & \multirow[t]{2}{*}{3.97} & High \\
\hline & $\begin{array}{l}\text { the best service without discriminating } \\
\text { disabled students }\end{array}$ & 0.0 & 0.0 & 10.0 & 83.3 & 6.7 & & \\
\hline 19 & $\begin{array}{l}\text { The aim of inclusive education is to } \\
\text { minimize isolation by encouraging }\end{array}$ & 0 & 0 & 2 & 26 & 2 & 4.00 & High \\
\hline & $\begin{array}{l}\text { special education students to participate } \\
\text { in school and community }\end{array}$ & 0.0 & 0.0 & 6.7 & 86.7 & 6.7 & & \\
\hline 20 & $\begin{array}{l}\text { Inclusive education program involves } \\
\text { special education students with minimum }\end{array}$ & 0 & 0 & 4 & 23 & 3 & 3.97 & High \\
\hline & $\begin{array}{l}\text { disability who can follow the mainstream } \\
\text { curriculum }\end{array}$ & 0.0 & 0.0 & 13.3 & 76.7 & 10.0 & & \\
\hline & $\begin{array}{l}\text { Total }(\mathrm{N})=30 \text { people } \\
\text { Overall mean }\end{array}$ & & & & & & 3.80 & High \\
\hline
\end{tabular}


Table 6. The Level of Use of Teaching Aids and Classroom Management in an Inclusive Class

\begin{tabular}{|c|c|c|c|c|c|c|c|c|}
\hline \multirow{2}{*}{$\begin{array}{l}\text { Item } \\
\text { No }\end{array}$} & \multirow[t]{2}{*}{ Question } & \multicolumn{5}{|l|}{ Scale } & \multirow[t]{2}{*}{ Mean } & \multirow[t]{2}{*}{ Level } \\
\hline & & $\begin{array}{l}\text { STS } \\
f \\
(\%)\end{array}$ & $\begin{array}{c}\mathrm{TS} \\
f \\
(\%)\end{array}$ & $\begin{array}{c}\mathrm{TP} \\
f \\
(\%)\end{array}$ & $\begin{array}{l}\mathrm{S} \\
f \\
(\%)\end{array}$ & $\begin{array}{c}\mathrm{SS} \\
f \\
(\%)\end{array}$ & & \\
\hline \multirow[t]{2}{*}{21} & \multirow[t]{2}{*}{ The material for teaching aids are prepared together } & 0 & 0 & 3 & 22 & 5 & \multirow[t]{2}{*}{4.07} & \multirow[t]{2}{*}{ High } \\
\hline & & 0.0 & 0.0 & 10.0 & 73.3 & 16.7 & & \\
\hline \multirow[t]{2}{*}{22} & \multirow{2}{*}{$\begin{array}{l}\text { The preparation of teaching aids burdens the } \\
\text { mainstream teachers }\end{array}$} & 1 & 4 & 4 & 18 & 3 & \multirow[t]{2}{*}{3.60} & \multirow[t]{2}{*}{ Average } \\
\hline & & 3.3 & 13.3 & 13.3 & 60.0 & 10.0 & & \\
\hline \multirow[t]{2}{*}{23} & \multirow{2}{*}{$\begin{array}{l}\text { The lack of teaching aids makes teaching and learning } \\
\text { more difficult in an inclusive class }\end{array}$} & 0 & 0 & 0 & 26 & 4 & \multirow[t]{2}{*}{4.13} & \multirow[t]{2}{*}{ High } \\
\hline & & 0.0 & 0.0 & 0.0 & 86.7 & 13.3 & & \\
\hline \multirow[t]{2}{*}{24} & \multirow{2}{*}{$\begin{array}{l}\text { Teaching aids are displayed and arranged according to } \\
\text { the subjects taught }\end{array}$} & 0 & 0 & 0 & 27 & 3 & \multirow[t]{2}{*}{4.10} & \multirow[t]{2}{*}{ High } \\
\hline & & 0.0 & 0.0 & 0.0 & 90.0 & 10.0 & & \\
\hline \multirow[t]{2}{*}{25} & \multirow{2}{*}{$\begin{array}{l}\text { Teachers use teaching aids such as radio, computer and } \\
\text { television in class }\end{array}$} & 0 & 0 & 5 & 21 & 4 & \multirow[t]{2}{*}{3.97} & \multirow[t]{2}{*}{ High } \\
\hline & & 0.0 & 0.0 & 16.7 & 70.0 & 13.3 & & \\
\hline \multirow[t]{2}{*}{26} & \multirow{2}{*}{$\begin{array}{l}\text { Table arrangement is adjusted to the students' needs } \\
\text { so that they will not have problems in following the } \\
\text { teaching of the teachers in class }\end{array}$} & 0 & 0 & 3 & 22 & 5 & \multirow[t]{2}{*}{4.07} & \multirow[t]{2}{*}{ High } \\
\hline & & 0.0 & 0.0 & 10.0 & 73.3 & 16.7 & & \\
\hline \multirow[t]{2}{*}{27} & \multirow{2}{*}{$\begin{array}{l}\text { Teachers give clear and understandable instructions } \\
\text { during the teaching and learning process }\end{array}$} & 0 & 0 & 1 & 24 & 5 & \multirow[t]{2}{*}{4.13} & \multirow[t]{2}{*}{ High } \\
\hline & & 0.0 & 0.0 & 3.3 & 80.0 & 16.7 & & \\
\hline 28 & Teachers do show examples or ways to do homework & 0 & 2 & 4 & 21 & 3 & 3.83 & High \\
\hline & & 0 & 6.7 & 13.3 & 70.0 & 10.0 & & \\
\hline 29 & Teachers do give students extra time to complete given & 2 & 3 & 1 & 21 & 3 & 3.67 & Average \\
\hline & tasks & 6.7 & 10.0 & 3.3 & 70.0 & 10.0 & & \\
\hline 30 & Teachers do drilling exercises in the process of & 2 & 0 & 0 & 25 & 3 & 3.90 & High \\
\hline & teaching and learning & 6.7 & 0.0 & 0.0 & 83.3 & 10.0 & & \\
\hline & $\begin{array}{l}\text { Total }(\mathrm{N})=30 \text { people } \\
\text { Overall mean }\end{array}$ & & & & & & 3.9 & High \\
\hline
\end{tabular}

Overall, it is concluded that the knowledge of teachers on the inclusive education program is at a high level with an overall mean of 3.80. Moreover, to achieve the mean of 4.00 in the research, teachers should be given knowledge on the three main techniques for inclusive education which are coteaching, collaboration and support teaching.

Section D: The Use of Teaching Aids and Classroom Management by Teachers in an Inclusive Class

Based on the research in table 6 , a majority of teachers stated that they do use teaching aids in the process of teaching and learning in an inclusive class and the overall mean is 3.90 . This shows a high mean level.

\section{Discussion}

The findings regarding teachers' acceptance on the implementation of inclusive education program as stated in Table 4 is supported by Block et al.
(2007) where it shows that teachers have a positive acceptance of this program. The commitment shown gives the teachers the much needed space and time to respect the attitude and opinion of these students. However, the findings of this research contrasted with the findings of Costello and Boyle (2013) where they said that the teachers' attitudes are less positive after a year of teaching these students due to acquirement of experiences and understanding of their tasks.

High results in the area of teachers' knowledge levels in this research was different from the research conducted by Omar, Tahar and Yasin (2012) who found that the attitude of the mainstream teachers was only at an average level in executing inclusive education. In addition, the finding in the level of teaching knowledge was supported by (Ocloo \& Subbey 2008; Chhabra et al., 2010) where they mentioned that lack of knowledge on inclusive education does influence the teachers in teaching special education students.

In the area of the use of teaching aids, the research finding is supported by a research when it mentioned 
that a weak classroom management will threaten the relationship between the students and school because a mismanaged classroom does not give a stable and conducive environment to cultivate effective learning (Blum 2005)

To answer the question on the relationship of approach used by the teachers during the teaching and learning process for students with hearing impairment in inclusive education program, the findings concluded that most teachers agree that they lack suitable teaching aids and this has hindered the activity of teaching and learning in an inclusive class. The recoded mean is 4.13 . The teachers should be given exposures by sending them for regular trainings conducted by experts in inclusive education so that problems could be eradicated to deliver information on learning and to facilitate these students.

\section{CONCLUSION}

This research has given a positive impact on the implementation of special education program. Among the noticeable impact is that teachers are interested to know how the next step of implementing inclusive education in schools improves collaboration between parents and the school community. Furthermore, the regular and special education teachers will be able to collaborate well together to implement learning activities for the students, as excellent collaboration is highly and frequently encouraged so that the implementation of the inclusive education program can become more effective.

This research can also be used as a feedback to teachers on the appropriate steps that should be taken to improve their level of acceptance towards the inclusive education program. Some of the suggested steps are: (1) The Education Ministry with the help of the Special Education Department have to formulate the existing curriculum by making them easier and suitable to students with hearing impairment to learn in an inclusive class; (2) Teachers should be given exposure and intensive trainings on the inclusive education program; (3) Teachers should be taught sign language; (4) Teachers should use various methods of learning and facilitating to attract student's attention.

\section{REFERENCE}

Ali, M. M., Azman, N., \& Jelas, Z. M. (2006). Sokongan ibu bapa, guru-guru, pelajar normal dan profesional kepada pelajar-pelajar khas di Malaysia. Prosiding Seminar Pendidikan Serantau Pekan Baru.
Block, M. L., Zecca, L., \& Hong, J. S. (2007). Microgliamediated neurotoxicity: uncovering the molecular mechanisms. Nature Reviews Neuroscience, 8(1), 57.

Blum, R. W. (2005). A case for school connectedness. Educational Leadership, 62(7), 16-20.

Booth, T., \& Ainscow, M. (2002). Index for inclusion: Developing learning and participation in schools. Centre for Studies on Inclusive Education (CSIE), Rm 2S203 S Block, Frenchay Campus, Coldharbour Lane, Bristol BS16 1QU, United Kingdom, England (24.50 British pounds).

Chhabra, S., Srivastava, R., \& Srivastava, I. (2010). Inclusive education in Botswana: The perceptions of school teachers. Journal of Disability Policy Studies, 20(4), 219-228.

Costello, S., \& Boyle, C. (2013). Pre-service secondary teachers' attitudes towards inclusive education. Australian Journal of Teacher Education, 38(4), 129-143.

Konting, M. J. (2004). Kaedah penyelidikan pendidikan. Kuala Lumpur: Dewan Bahasa dan Pustaka.

Miles, S., \& Singal, N. (2010). The Education for All and inclusive education debate: conflict, contradiction or opportunity?. International journal of inclusive education, 14(1), 1-15.

Ocloo, M.A. \& Subbey, M. 2008. Perception of basic education school teachers towards inclusive education in the Hohoe District of Ghana. International Journal of Inclusive Education, 12(5-6), 639-650.

Omar, R. C., Tahar, M. M., \& Yasin, M. H. M. (2012). Kesediaan Guru-Guru Aliran Perdana Mengajar Pelajar Bermasalah Pembelajaran dalam Pendidikan Inklusif. Seminar Internasional Pasca Siswazah Pendidikan Khas UKM-UPI Siri II 2012, 4, 484-494.

Teng, L. K., Elkin, J., Lim, L. \& Sim, W. K. (2006). Learning assistance and regular teacher's perception of inclusion in brunei Darussalam. International Journal of Special Education 21(1),131-143.

Valeo, A. (2008). Inclusive Education Support Systems: Teacher and Administrator Views. International Journal of Special Education, 23(2), 8-16.

Yasin, M. H. B. M., Toran, H. B., \& Shaari, S. B. (2008). Pelaksanaan Program Inklusif di Sekolah Menengah Teknik dan Sekolah Menengah Harian. Educationist, 2(1), 44-45.

Zalizan, M. J. (2012). Pendidikan Kanak-kanak Berkeperluan Khas: Konsep \& Amalan. Fakulti Pendidikan, Universiti Kebangsaan Malaysia, 109-138. 